\title{
Krzysztof Loska
}

\section{Przemoc kolonialna, strategie oporu i przywracanie pamięci w filmie Wei Te-shenga Wojownicy tęcay}

Punktem wyjścia jest założenie, że kino stanowi ważny głos w debacie na temat pamięci historycznej, pokazuje ambiwalentny stosunek do przeszłości i jest środkiem przekazu poruszającym kwestie polityczne oraz kulturowe. W swoim artykule przyjmuję perspektywę postkolonialną, uwzględniając nie tyle dziedzictwo zachodniego imperializmu, co raczej jego dalekowschodnią odmianę. Po drugie, wskazuję na istotne podobieństwa między różnymi rodzajami przemocy, które prowadzą do podporządkowania lub zniszczenia kultury podbitego narodu. Po trzecie, zastanawiam się nad sposobami przedstawiania historii i możliwością przywracania pamięci za pomocą sztuki filmowej. Przedmiotem analizy jest film tajwańskiego reżysera Wei Te-shenga Wojownicy tęczy (Warriors of the Rainbow: Seediq Bale, 2011), w którym dostrzegam przykład nowoczesnego kina politycznego w rozumieniu Gilles'a Deleuze’a.

Słowa klucze: przemoc, kolonializm, postkolonializm, pamięć, opór, kino, Wei Te-sheng

Patrycja Włodek

\section{Krytyczne retro a kształtowanie pamięci zbiorowej w kinie amerykańskim XXI wieku}

Jednym $\mathrm{z}$ aspektów retromanii jest przywracanie/konstruowanie pamięci o minionych epokach we współczesnej popkulturze. W tekście dominuje spojrzenie na krytyczne retro w kinie amerykańskim XXI wieku jako na sposób, w jaki filmowe środki wyrazu są wykorzystywane do budowania określonego wyobrażenia o relatywnie nieodległej przeszłości i konstruowania obejmującej ją pamięci zbiorowej. Znaczenie ma to, w jaki sposób pamięć zbiorowa jest wytwarzana i przechowywana w wytworach kultury, także w kinie, twórcy krytycznego retro posługują się bowiem zestawem wyrazistych, rozpoznawalnych strategii, takich jak - między innymi - samoświadomość wizualna, cytaty intertekstualne, stosowanie oswojonych konwencji do wypełniania luk w narracjach (i w pamięci). Co istotne, robią to z wyraźną intencją budowania/ odzyskiwania pamięci i historii grup społecznych wykluczanych z tych obszarów we wcześniejszej kulturze dominującej.

Słowa klucze: retro, nostalgia, film nostalgiczny, krytyczne retro, studia pamięciologiczne, pamięć zbiorowa 


\section{Tomasz Gnat}

\section{Niepamięć operacyjna. Dyskursy pamięci, zapomnienia i post-pamięci w rozrywce interaktywnej}

W niniejszej pracy podejmuję się analizy narzędzi, które wykorzystywane są, by usprawnić procesy pamięci w grach wideo. Dyskusję otworzy przyjrzenie się metodom stosowanym przez twórców gier, by pogodzić antytetyczne nurty dyskursu - strukturalną narrację i interaktywną naturę medium. Analizie poddane zostaną zarówno klisze narracyjne w postaci trop amnezji, jak i nowatorskie techniki, które wykorzystują narzędzia charakterystyczne dla rozrywki interaktywnej. W drugiej części przedstawione zostaną perspektywy na specyficzną rolę pamięci nie tylko w kwestiach narracyjnych, ale również $w$ aspektach gier jako medium. Tutaj przede wszystkim analizowane będzie wyjście poza tradycyjne postrzeganie pamięci, przejście od bazy danych do interaktywnego procesu, prowadzące do konstrukcji nowych form i mechanizmów narracyjnych. Badane będą takie zjawiska jak tworzenie się pamięci zbiorowej i pamięci transaktywnej w subkulturach rozrywki interaktywnej. Jednym z podstawowych założeń tej analizy będzie teza, że w porównaniu do narracji tradycyjnych, w grach wideo znacznie ważniejszą rolę odgrywają procesy niepamięci, zapomnienia i post-pamięci, rozumianej jako wypadkowa poprzednich pojęć. Taki sposób reinterpretacji wspomnień będzie w dużym stopniu kształtował naszą percepcję pojęcia temporalności w rozrywce interaktywnej. Będzie wymagał odejścia od tradycyjnej perspektywy czasu i przejście do interpretacji czasu z perspektywy Bergsona i Deleuze'a.

Słowa klucze: pamięć, post-pamięć, rozrywka interaktywna

\section{Justin Michael Battin i Elle Rystakova}

\section{Heideg̊ger i aktywizm fanów. Manifestacje poiēsis we współczesnej mobilizacji społeczności online}

Artykuł ten czerpie inspirację z obu tez Heideggera przedstawionych w przełomowym eseju The Question Concerning Technology (1977 [1956]) oraz z jego interpretacji poiēsis, konceptu omawianego przez filozofa w wielu z jego późniejszych prac. Celem artykułu jest ukazanie poiēsis jako wielowymiarowej siły napędowej u podstaw działań aktywistów prowadzących skuteczne kampanie w Internecie. Aktywizm fanów, w przeciwieństwie do tzw. solidarności kliknięcia myszą (tzw. slacktywizmu), jest formą działalności w mediach społecznościowych bazującą na uprzednim zaangażowaniu użytkownika $\mathrm{w}$ dany tekst, którego treści - w jego odbiorze - pozwalają interpretować problemy świata pozatekstowego. Heideggerowska interpretacja poiēsis jest dla tej relacji komponentem o kluczowym znaczeniu. Poiēsis bowiem stanowi iskrę, która rozpala, a potem podtrzymuje kampanie fanów-aktywistów, ponieważ jest czynnikiem uświadamiającym nam, jak świat na nas wpływa, ale jednocześnie w jaki sposób my sami weń się angażujemy lub jak w nim funkcjonujemy, zgadzając się na jego zasady. Wychodząc od analiz kampanii prowadzonych przez fanów-aktywistów, niniejszy artykuł dowodzi, że rewitalizacja istoty poiēsis w naszym codziennym życiu - a w szczególności w sferze naszej jaźni wspólnotowej - ma elementarne znaczenie dla ożywienia poczucia zaangażowania 
w kształtowanie rzeczywistości świata, w którym żyjemy, a w konsekwencji dla rewizji umiejscowienia w nim człowieka i jego roli jago szczególnego agensa transformacji.

Słowa klucze: studia nad mediami, filozofia, mobilne media społecznościowe, Harry Potter Alliance, media cyfrowe, fenomenologia, filozofia kontynentalna

\section{Małgorzata Cieliczko}

\section{Codzienność (od)pamiętana. Projekt „autobiografii zbiorowej” Georges'a Pereca}

Czy błędne wspomnienia mogą być prawdziwe? Co stanowi fundament kultury - trwały mit, a może zmienna codzienność? Czy można stworzyć autobiografię zbiorową? A jeśli tak, czym taki gatunek miałby się charakteryzować? Między innymi z takimi pytaniami mierzy się autorka artykułu, biorąc na teoretyczny i interpretacyjny warsztat Pamiętam że (1978, przeł. Krzysztof Zabłocki) Georges’a Pereca. Książeczka zbudowana jest z 480 krótkich wspomnień, jednozdaniowych „okruchów codzienności”, błahych drobiazgów sprzed lat i przez lata odpamiętywanych. Ten prosty koncept z pogranicza poetyki i „pracy przypominania” przynosi fascynujące rezultaty; nie tylko buduje alternatywny dla historycznych przekazów obraz powojennej Francji, ale przede wszystkim istotnie oddziałuje na czytelnika - także współczesnego, także polskiego. Zderzenie tego tekstu z kategoriami pamięci komunikatywnej i pamięci kulturowej Jana Assmanna pozwala podjąć refleksję m.in. nad indywidualnością i zbiorowością wspomnień oraz rodzajem pamięci, która rzeczywiście łączy pokolenia i kultury.

Słowa klucze: autobiografia zbiorowa, pamięć komunikatywna, pamięć kulturowa, codzienność, Georges Perec, Jan Assmann

\section{Anna Maria Bielak}

\section{Życiodajne archiwum. Składowiska pamięci w dziele Alberta Cohena}

W niniejszym artykule stawiam sobie za cel uchwycenie i przeanalizowanie kilku z kluczowych tematów pisarstwa Alberta Cohena za pomocą pojęcia archiwum Jacques'a Derridy. Obecność doświadczenia narodu wybranego jest niezmiennie obecna dla tekstów Cohena. Czytelnik nie ma żadnych wątpliwości co do jego wpływu na narrację. W swoim artykule chciałabym pokazać, że w ten sposób rozumiany proces pisania Cohena znacznie wykracza poza zwykłe myślenie o przeszłości czy nawet o żydowskiej tożsamości, która zawsze w jakiś sposób podtrzymuje relację z przodkami. Wykorzystanie derridiańskiego pojęcia archiwum umożliwia zaobserwowanie, jak wielka jest aktywność przeszłości i jaki jest jej impakt na kształt tożsamości podmiotu. Doświadczenie narodu wybranego w dziele Alberta Cohena pozostaje niezmiennie obecne, a owa obecność narzuca refleksję narratorowi, kolejnym protagonistom fikcji, w końcu czytelnikowi. Chodzi tu o znacznie więcej niż o ślad przeszłości, o więcej niż jej opisywanie czy rozpamiętywanie; być może o więcej niż o aktywny czynnik tożsamości. Wykorzystując pojęcie archiwum Jacques’a Derridy, chciałabym przyjrzeć się bliżej kilku kluczowym motywom i charakterystycznym cechom stylu Cohenowskiej prozy. Wychodząc od analizy kluczowych dla indywidualnego, osobistego strukturyzowania pamięci figur matki i ojca, ocierając się niekiedy o pojęcie traumy, zamierzam zaproponować odczytanie żydowskiej piwnicy, która staje się toposem 
twórczości żydowskiego pisarza, jako wiecznie żywego i nieskończenie otwartego składowiska wspomnień i znaków tożsamości.

Słowa klucze: Albert Cohen, archiwum, pamięć

\section{Urszula Gołębiowska}

\section{Pamięć i zapominanie w Pogrzebanym olbrzymie Kazuo Ishigury}

Celem artykułu jest odczytanie najnowszej powieści Kazuo Ishigury jako refleksji pisarza nad rolą pamięci i zapominania w życiu indywidualnym i zbiorowym. Wydany w 2015 roku Pogrzebany olbrzym odnosi się do kwestii niezmiennie aktualnej, dotyczącej zarówno jednostek jak i społeczeństw próbujących uporać się z traumatyczną przeszłością. Mimo że Ishiguro nie udziela łatwych odpowiedzi na pytanie o to, czy pamiętać o trudnych wydarzeniach, czy raczej je wymazać, tymczasowa amnezja jawi się w powieści jako uzasadniony zabieg, pozwalający jednostkom utrzymać relacje, a społeczeństwom uniknąć ponownego wybuchu przemocy. Zjawisko pamięci zbiorowej, problem pamięci, która nieuchronnie powraca po okresie amnezji/ amnestii i jej uwikłania w konkurujące ze sobą polityki pamięci, wzajemne powiązanie pamięci i zapominania, rola pamięci mimowolnej w podważaniu oficjalnej narracji to kwestie, które powieść porusza i które zostały omówione w artykule w odniesieniu do dwudziestowiecznych koncepcji i dyskursów na temat pamięci: Maurice’a Halbwachsa, Waltera Benjamina, Marcela Prousta, a także współczesnego brytyjskiego filozofa Galena Strawsona.

Słowa klucze: Ishiguro, amnezja, amnestia, pamięć zbiorowa, pamięć mimowolna, polityka pamięci

\section{Jan Moryń}

\section{Umieć sobie wybaczyć \\ Widmontologiczne ujęcie Umiłowanej Toni Morrison}

Przedmiotem niniejszego artykułu jest powieść Umiłowana autorstwa Toni Morrison oraz odczytanie jej z perspektywy widmontologicznej. Umiłowana jest powieścią wpisującą się w dyskurs dotyczący pamięci w literaturze ze względu na swoją retrospektywną naturę: rzeczywistość w dziele Toni Morrison jest aktywnie kształtowana przez przeszłość oraz nawiedzana przez widma minionych koszmarów oraz nieżyjących postaci. Pośród zagadnień poruszonych w tej pracy znajdują się różnice pomiędzy pamięcią a interpretacją, traumy pamięci oraz relacja pomiędzy pamięcią a tożsamością. Zarówno wydarzenia jak i postaci występujące w utworze charakteryzują się ambiwalencją, kontestacją binarnych przeciwieństw (obecność/abscencja; życie/śmierć; wolność/niewola) oraz są podszyte szeregiem nadających im znaczenia śladów. Pomimo że cechy te wskazują na dekonstrukcjonizm jako teorię odpowiednią do rozszyfrowania powieści, artykuł proponuje spojrzenie na Umiłowaną przez pryzmat widmontologii. Praca ta przedstawia widmontologię jako teorię krytyki literackiej zdolną do wyprodukowania interesującego odczytania powieści, oraz zaznacza różnice dzielące widmontologię od teorii traumy, jednej z dominujących teorii wykorzystywanych w analizowaniu Umiłowanej. Ten artykuł posługuje się teorią widmontologii proponowaną przez Jacques’a Derridę, Marka Fishera, Jodey Castricano oraz Andrzeja Marca.

Słowa klucze: widmontologia, Toni Morrison, Beloved, Umiłowana 


\section{Katarzyna Czech}

\section{Mityzacja Katastrofy smoleńskiej w filmie Antoniego Krauzego i poezji smoleńskiej jako funkcja pamięci zbiorowej}

Katastrofa prezydenckiego samolotu z 10 kwietnia 2010 roku wywołała szereg reakcji artystycznych. W odpowiedzi na nią powstały m.in. zebrane w Antologii smoleńskiej. 96 wierszy utwory poetyckie oraz film Smoleńsk Antoniego Krauzego. Oba teksty kultury łączy wspólna wizja wydarzeń z 10 kwietnia, którą usiłują włączyć w krąg powszechnie obowiązującej i akceptowanej polskiej pamięci zbiorowej. Stanowią jednocześnie formę zapisu pamięci oraz narzędzie ją kształtujące, a efektem tych artystycznych projektów pamięciowych jest wytworzenie narracji, którą za Pawłem Sendyką nazwać można mitem smoleńskim. Zarówno język filmowy, jak i narzędzia literackie wykazują potencjał eksplanacyjny, pozwalający na usensownienie rozbitej przez tragedię smoleńską rzeczywistości. Niezwykłe, nacechowane symbolicznie i podatne na interpretacje okoliczności tragedii sprawiły, że w narracji na jej temat ścierają się odmienne typy pamięci. Film Krauzego oraz teksty poetów smoleńskich biorą aktywny udział w konstruowaniu i utrwalaniu wizji „zamachu smoleńskiego”, snutej przeciwko opowieści o „katastrofie smoleńskiej”. Aby tego dokonać, sięgają do tradycji romantycznej, wzorców martyrologicznych i religijnych. Przeszłość przetworzona przez pamięć zyskuje wymiar sakralny i staje się mitem osadzonym na znaturalizowanej kategorii „prawdy historycznej”. Przyjrzenie się filmowi Krauzego oraz wybranym wierszom z Antologii smoleńskiej... pozwala zarysować węzłowe punkty mitu smoleńskiego - określonej wizji katastrofy, czy raczej zamachu smoleńskiego, pretendującej do zajęcia pozycji dominującej w powszechnej pamięci zbiorowej.

Słowa klucze: Smoleńsk, poezja smoleńska, zamach smoleński, pamięć zbiorowa, pamięć kulturowa, katastrofa smoleńska

Erin Heisel

\section{Ekspansja i kontrakcja \\ Todd and the Vampire a przestrzenie sztuki}

Co dzieje się, kiedy muzyka i przestrzeń operowa, tradycyjnie prezentowane „na żywo”, zostają poddane procesowi digitalizacji? Jakie konsekwencje dla społeczności artystów niesie ze sobą ich odizolowanie, kiedy przestrzeń tworzenia z teatru - miejsca relacji interpersonalnych - przeniesiona zostaje w świat wirtualny? Jakie taka zmiana rodzi możliwości i niebezpieczeństwa dla twórców? Czy można dostrzec tu podobieństwa z innymi dziedzinami sztuki, które powstały lub rozwinęły się w oparciu o technologie nowych mediów? Niniejszy artykuł rozważa powyższe kwestie w kontekście powstawania animowanej opery/filmu youtubowego Todd and the Vampire, skomponowanego i stworzonego przez Ronena Shaia oraz przy udziale muzyków i przedstawicieli sztuk wizualnych pracujących równolegle, choć niezależnie, w różnych miejscach świata. W jaki sposób ostateczny produkt wykorzystuje technologię by rzucić wyzwanie i wyjść poza tradycyjne rozumienie przestrzeni i tożsamości? I wreszcie, jakie konsekwencje niesie ze sobą ów nieco odcieleśniony twórczy proces dla artystów, odbiorców i dla samej sztuki?

Słowa klucze: opera, muzyka, śpiew, animacja, przestrzeń, media, ucieleśnienie 


\section{Sławomir Masłoń}

\section{Prostytucja i sztuka. Panny z Awinionu Picassa \\ i zmienne koleje autentyczności}

Artykuł ma na celu zakwestionowanie sensowności tych interpretacji Panien z Awinionu, które poszukają jego znaczenia, odwołując się do stanu umysłu Picassa w okresie, w którym obraz powstawał, i traktują to dzieło jako wyraz zmagania się artysty z osobistymi demonami. Oferowana tu interpretacja obu wersji obrazu wskazuje, że był on odpowiedzią na Le bonheur de vivre Matisse’a i zarazem jego krytyką. Co więcej, odwołanie się do teorii Lacana pozwala autorowi nie tylko objaśnić pozorne niekonsekwencje Panien z Awinionu, lecz także pokazać, że ostateczna wersja tego dzieła jest metaobrazem, który ukazuje proces powstawania reprezentacji.

Słowa klucze: Picasso, spojrzenie, autentyczność, krytyka biograficzna

\section{Marcela Kościańczuk}

\section{Trzecie pokolenie Palestynek po Nakbie Postpamięć jako balansowanie „pomiędzy” komunikacją indeksalna, i symbolicznac}

Artykuł przedstawia narracje i fotografie wykonane przez Palestynki pochodzące z trzeciego pokolenia po Nakbie w świetle koncepcji komunikacji indeksalnej i symbolicznej, którymi młode kobiety posługują się naprzemiennie, budując własną narrację postpamięci. W artykule odwołuję się do Marianne Hirsch i jej teorii postpamięci, koncepcji Rolanda Barthes'a, Georges'a Didi-Hubermana, Susan Sontag, celem stworzenia teoretycznej ramy dla analiz fotografii i narracji Palestynek, z którymi przeprowadzałam fotowywiady.

Słowa klucze: Palestynki, postpamięć, komunikacja indeksalna, komunikacja symboliczna 